\title{
Economic and institutional aspects of wine consumption in the context of globalization and climate change in Europe and Russia
}

\author{
Miroslava Navrátilová \\ Czech University of Life Science Prague, Prague, Czech Republic \\ e-mail: navratilovam@pef.czu.cz \\ Markéta Beranová \\ Czech University of Life Science Prague, Prague, Czech Republic \\ e-mail: mberanova@pef.czu.cz \\ Lucie Severová \\ Czech University of Life Science Prague, Prague, Czech Republic \\ e-mail: severova@pef.czu.cz
}

Citation: Navrátilová M., Beranová M., Severová L. (2021). Economic and institutional aspects of wine consumption in the context of globalization and climate change in Europe and Russia. Terra Economicus 19(4): 127-140. DOI: 10.18522/2073-6606-2021-19-4-127-140

For centuries, wine has played an important role in the economic institutions of food security and agri-food complex. However, due to the globalization and economic development wine industry has been in the midst of a number of changes and new challenges in recent decades, to which it is forced to respond in order to maintain its competitiveness and economic efficiency. Changing consumer preferences and requirements lead to the changes in wine consumption around the world. New territories enter the wine market, which modifies the institutions and the mode of the wine trade from a global perspective. All these aspects resonate with the climate change. Wine as a crop is highly sensitive to climatic and soil conditions which results in the extraordinary sensitivity of the entire viticulture and wine-making sector. Our paper evaluates wine consumption in selected European countries and Russia in the context of climate using the beta convergence method. Beta convergence was used as research method, through which changes in differences between selected countries whose consumption exceeds 2 million hectoliters were examined. The basic sample consisted of 14 countries from Europe and Russia. The results show that globalization processes are blurring some of the differences between countries, which are converging in terms of wine consumption in the long run. At the same time, however, it can be stated that the influence of natural conditions and historically given peculiarities cannot be disregarded. National customs are also historically adapted to the climate, including the preferred types of beverages.

Keywords: institutional change; beta convergence; climate change; wine consumption; food security

Funding: This work was funded by the Faculty of Economics and Management, Czech University of Life Sciences in Prague (Internal Grant Agency, IGA) under Grant number 2020B0002 - "The impact of climate change on the economic performance of the viticulture and wine-making sector in the Czech Republic".

JEL codes: $D 10$, L66 


\title{
Экономические и институциональные аспекты потребления вина в контексте глобализации и климатических изменений в Европе и России
}

\author{
Мирослава Навратилова \\ Чешский сельскохозяйственный университет в Праге, Прага, Чешская Республика \\ e-mail: navratilovam@pef.czu.cz \\ Маркета Беранова \\ Чешский сельскохозяйственньй университет в Праге, Прага, Чешская Республика \\ e-mail: mberanova@pef.czu.cz \\ Люцие Северова \\ Чешский сельскохозяйственньй университет в Праге, Прага, Чешская Республика \\ e-mail: severova@pef.czu.cz
}

Цитирование: Navrátilová M., Beranová M., Severová L. (2021). Economic and institutional aspects of wine consumption in the context of globalization and climate change in Europe and Russia. Terra Economicus 19(4): 127-140. D0I: 10.18522/2073-6606-2021-19-4-127-140

На протяжении веков вино играло важную роль в экономических институтах продовольственной безопасности и агропродовольственного комплекса. Однако в связи с глобализацией и экономическим развитием винная промышленность в последние десятилетия столкнулась с рядом изменений и новых вызовов, на которые она вынуждена реагировать, чтобы сохранить свою конкурентоспособность и экономическую эффективность. Изменение потребительских предпочтений и требований приводит к изменению потребления вина во всем мире. Кроме того, на винном рынке появляются новые территории, что меняет институты и форму торговли вином с глобальной точки зрения. Все эти аспекты перекликаются с изменением климата. Виноградарство и виноделие чрезвычайно чувствительны к климатическим и почвенным условиям. В нашей статье потребление вина в отдельных странах Европы и России оценивается в контексте климата с использованием метода бета-конвергенции. Были изучены изменения в различиях между отдельными странами, потребление которых превышает 2 миллиона гектолитров. Базовая выборка состояла из 14 стран Европы и России. Результаты показывают, что процессы глобализации стирают некоторые различия между странами, которые в долгосрочной перспективе сближаются с точки зрения потребления вина. В то же время можно констатировать, что нельзя не учитывать влияние природных условий и исторически заданных особенностей. Национальные обычаи исторически адаптированы к климату, а также включая предпочтительные виды напитков.

Ключевые слова: институциональные изменения; бета-конвергенция; изменение климата; потребление вина; продовольственная безопасность

Финансирование: Эта работа финансировалась факультетом экономики и менеджмента Чешского сельскохозяйственного университета в Праге (агентство внутренних грантов, IGA) в рамках гранта № 2020 В0002 - «Влияние изменения климата на экономические показатели виноградарства и виноделия в Чешской республике». 


\section{Introduction}

The economic, technological, social and cultural development of recent decades has led to profound changes in society, primarily through modifications of production and consumption systems (Platania et al., 2016) and economic institutions (Davidson et al., 2018; Hinings et al., 2018). An actual shift towards more sustainable practices can also be observed in the agri-food complex, which can be attributed to the growing concern for the corporate social and environmental responsibility both in the sector of agriculture and in other sectors of the economy (Zucca et al., 2009; Abrhám, Lžičař, 2018; Khoshnava et al., 2019; Tyslová et al., 2020). The role of agriculture in the national economy of individual states has changed during their economic development, but its importance for the existence of mankind remains unchanged (Beňuš et al., 2021; Marunelu, 2020; Pretty et al., 2018).

Viticulture, wine production and consumption have an irreplaceable place in the history of mankind (Maicas, Mateo, 2020). Vine growth demands very specific climatic and soil conditions and can only be grown in selected areas that are suitable for this purpose (Mosedale et al., 2016; Hannah et al., 2013).

The wine industry is currently geographically divided into the Old World and the New World (Werdelmann, 2014). Van Leeuwen and Seguin (2007) understand "terroir" as an element that relates the sensory properties of wine and the environmental conditions in which the grapes are grown. "Terroir" includes many factors, such as climate, soil quality, vine variety or production processes that interact, and to some extent it defines the quality of the final product.

With regard to the above, Werdelmann (2014) considers wine to be an interesting and complex product with characteristic properties that significantly distinguish it from other standardized, typically produced goods. Moreover, Platania et al. (2016) consider wine as a specific product that combines elements of tradition with the need for constant innovation.

Until the early 1990s, wine consumption and production were relatively localized (Werdelmann, 2014). Until then, wine producers in individual countries had been isolated from each other and most consumers consumed either wines of local origin or imported from neighboring countries (Cholette, Castaldi, 2005). Aylward (2003) states that since the 1980s, changes in the situation of the wine industry can be observed in terms of the changing significance of the so-called "New" and "Old-World" countries. The market share of the so-called New World countries in world trade gradually increased. This led to the changes in the structure of the global wine industry (Kirovski, 2011) and its competitive environment (Radović, Milićević, 2020). In the 1990s, New World wines (the countries of North and South America, Australia, New Zealand and South Africa) appeared on the world market at a very favorable price. These wines met the expectations of especially young consumers (Radović, Milićević, 2020). Kirovski (2011) considers the favorable climatic conditions for the cultivation of vines in the given countries, the motivation and stimulation of wine production through government intervention and the application of scientific results and innovations to be the main reasons for the successful expansion of New World wines. At the same time, wine production in traditional European producer countries (France, Italy, Spain, etc.) gradually decreased during this period (Radović, Milićević, 2020). While in the 1980s the share of European countries in world wine exports was about $96 \%$, in 2000 it was only 68.1\% (Aylward, 2003). From the point of view of the world wine industry, vine production and emerging consumer markets in the so-called third world countries, especially India and China, cannot be neglected (Banks, Overton, 2009).

In the context of the globalization of the wine sector, a new international approach can be seen, consisting primarily of reducing tariffs and logistics costs and the overall mitigation of barriers to international trade. These new facts allowed producers to expand into new markets and provided a competitive advantage (Jamali, 2020; Cholette, Castaldi, 2005). The wine industry is currently global in nature and complex in an international context (Cradock-Henry, Fountaine, 2019; Thorpe, 2009). At the same time, however, the wine market is highly diversified and differentiated (Werdelmann, 2014).

The world wine production in the first decade of this century can be characterized as very volatile with significant fluctuations. In the 2010s, substantial changes occurred in the structure of wine production in the countries with the largest volumes of production. In part, this can be attributed to the reforms that were induced in the EU wine sector (several of these reforms have taken place) (Katunar et al., 2021; Pomarici, Sardone, 2020). In 2020, global wine production was 260 million hl, an increase of 1\% compared to 2019 (OIV, 2021). 
The EU has long been involved in viticulture under the Common Agricultural Policy, and the wine sector is still a very important part of EU agriculture (Katunar et al., 2021; Pomarici, Sardone, 2020). Ferrer Lorenzo et al. (2018) note that the European wine sector has undergone significant changes in recent years. The area under vines has decreased, but production has been maintained, mainly thanks to restructuring and improvements in harvesting techniques. At the same time, however, there has been a reduction in wine consumption, which has led to a significant increase in competition in the sector.

The area of vineyards in the European Union can be considered stable, reaching 3.3 million hectares in the last seven years. Between 2020 and 2019 there was a decrease in the area of vineyards in Spain (961 thousand ha, $-0.6 \%$ ), Portugal (194 thousand ha, $-0.2 \%$ ), Bulgaria ( 66 thousand ha, $-1.8 \%$ ) and Hungary ( 65 thousand ha, $-3.9 \%$ ), while in some countries there was a slight increase in the area of vineyards, for example in France (797 thousand ha, $+0.4 \%$ ) and Italy (719 thousand ha, $+0.8 \%$ ). In Eastern Europe, the trend in the decline of the area of vineyards in Moldova continued. It began in 2018 and reached an area of vineyards of 140,000 ha (-2\% compared to 2019), in Russian vineyards, on the other hand, in 2020 there was a slight increase in the area of vineyards to 96 thousand ha (+0.6\% compared to 2019) (Apopei, Papaghiuc, 2021; 0IV, 2020).

Wine production has a long tradition in some European countries and an important position in the national economy (Janšto et al., 2018). There are currently strong initiatives in these countries to defend and preserve the cultural traditions of wine production and consumption (Radović, Milićević, 2020). This is also confirmed by Cox and Bridwell (2007), who rank wine among traditional European goods, both in terms of production and consumption.

In 2020, production in the European Union was 165 million hl, an increase of 8\% (+12 million hl) compared to the low volume recorded in 2019. This was despite the expected low demand, and the favorable weather also played a role, yielding a rich harvest in many EU regions (Apopei, Papaghiuc, 2021; OIV, 2020). In contrast, wine production in Eastern Europe decreased slightly in 2020, namely in Russia (4.4 million hl, $-4 \%$ compared to 2019) and Ukraine (0.7 million hl, $-33 \%$ compared to 2019).

From a global perspective, wine consumption can be considered fluctuating. The last decade has been characterized by slight fluctuations, with global wine consumption of 244 million hl in 2018, 241 million hl in 2019 and a further decline occurred in 2020, when wine consumption reached only 234 million hl resulting in decrease of 3\% compared to 2019 (Richter, Hanf, 2021; 0IV, 2020). Although this is the lowest level of wine consumption recorded since 2002, given the uncertainty in 2020 , this figure suggests that the wine sector, with respect to other sectors, is performing well in the context of individual commodities. The first year of the COVID-19 pandemic crisis pointed to the asymmetric behavior of consumers in different countries of the world (OIV, 2020). In 2020, the EU accounted for around $48 \%$ of global wine consumption. However, it must be taken into account that there have been changes in consumption within individual EU member states (OIV, 2020).

Agriculture is highly dependent on climatic conditions not only during the growing season of crops, which significantly affects their global production (Koch, Oehl, 2018; van Leeuwen, Darriet, 2016). The total amount of wine produced is affected by the risks reflected in fluctuations in annual yields. The growing and harvesting of grapes is significantly influenced by various natural conditions (Radović, Milićević, 2020), the most important of which can be considered the highly specific demands of this plant on soil and climatic conditions (Mosedale et al., 2016; Hannah et al., 2013). Given the ever-changing climatic conditions, new challenges are expected in the wine-making and viticulture sector, as vine growing is deeply dependent on them (Santos et al., 2020; Green, 2018).

Winter rest and a stable climate, which is not disturbed by significant temperature fluctuations, are important for the successful growth of vine, the vegetation period of vine being 180 days (Duchêne et al., 2010). It can be said that the vine harvest has a twofold relationship with climate trends; on one hand, the harvest is a function of the seasonal climate, on the other hand, it provides a criterion for classifying different vine varieties according to their relationship to the climate. In general, data from different areas of grapevine production offer a picture of earlier fruit ripening patterns with a subsequent shift forward at harvest time (Berbegal et al., 2019; Mira de Orduna, 2010). Changing climate trends require and will in the future require the implementation of timely, appropriate and cost-effective adaptation strategies that will be of the utmost importance for maintaining the socio-economic and environmental sustainability of the wine sector in Europe and worldwide (Santos et al., 2020). 
The aim of the presented paper is to evaluate the consumption of wine in selected countries of Europe and Russia in the context of climate through the beta convergence method. The paper is structured into the following sections. The Introduction contains basic knowledge from the literature and provides an overview of the issue. The Research objectives and methodology section lists the methods used to elaborate the article and characterizes the data used. The Conclusion summarizes the most important findings and lists the limits of the article and its other possibilities.

\section{Research objective and methodology}

According to the recommendations of Hendl and Remr (2017), three areas were taken into account in the elaboration of the theoretical basis, namely the theory on the given topic, similar empirical studies on the given topic and methodological literature. Therefore, scientific articles, professional books and current statistical data from official sources were used to determine a suitable theoretical framework (Koudelková et al., 2015; Mohajan, 2018). The performance of the analysis itself was based on a comparison of secondary data and documents, taking into account their identification price on the basis of criteria according to Hendl (2005). These were mainly official documents of the International Organization of Vine and Wine, the Statista internet portal and the Eurostat database. Information on average temperatures in individual countries was obtained from the Climate Change Knowledge Portal, which is operated by the World Bank Group. Continuous time series were created from the obtained data and were further analyzed and processed in order to create a suitable basis for calculations, subsequent interpretation and implementation of the overall evaluation.

Different methodologies are used in different information sources to report wine consumption per capita. Thus, there are slight deviations in terms of the interpretation of individual values. Some sources state wine consumption as a simple share of reported wine consumption and population, others state the share of total consumption and population over 15 years of age, in some sources the authors report only wine consumption excluding sparkling wine. To ensure the homogeneity of the results, data on total wine consumption, including sparkling wines in the individual countries observed, were used in the calculations carried out under this article, and a conversion was made to the total population.

Time series on total wine consumption were obtained from the annual statistical surveys of the OIV, which collects and publishes statistics on all countries with a significant share of wine production or consumption. Data published by this institution are also taken over by other organizations and official sources. However, detailed information on several dozen countries is available on the OIV website only until 2014. Since 2015, published data in less detailed reports focuses only on the main producer or consumer countries with consumption over 1 million hectoliters per year, for 2019 and 2020 only data on countries with consumption over 2 million hectoliters of wine per year are available. Therefore, only a group of European countries with a consumption of over 2 million hectoliters was selected for further analysis in order to work with the most up-to-date data set possible.

Descriptive statistics tools were used to describe the variables. The trends in wine consumption were evaluated by regression analysis, using the beta convergence method.

Convergence hypotheses were verified by beta convergence testing. Beta convergence examines the growth dynamics of a given indicator depending on its size. It determines whether countries with a lower value of a given indicator show higher growth dynamics in this period. In the literature, the term convergence refers mainly to Gross domestic Product (GDP) (Young et al., 2008; Barro, Sala-i-Martin, 2003). The tools for examining convergence are general and therefore allow to study any heterogeneity in the economy. Barro and Sala-i-Martin (2003) illustrate this fact with an example of a survey of population income. The description of convergence is theoretically based on the neoclassical theory of economic growth, more specifically on the Solow-Swan model (Barro, Sala-i-Martin, 2003). According to this model, states should have converged towards the same economic level in the long run. The basic formula according to Barro and Sala-i-Martin (2003) was adjusted to the form in which the calculations were performed:

$$
\frac{1}{T} \log \left(\frac{y_{i, t_{0}+T}}{y_{i, t_{0}}}\right)=B+\beta \cdot \log \left(y_{i, t_{0}}\right)+u_{i, t_{0}, t_{0}+T},
$$


Where $\mathrm{T}$ is the length of the survey period, $\mathrm{yi}, \mathrm{t} 0+\mathrm{T}$ is the magnitude of the $\mathrm{i}$-th economy indicator at the end of the period under investigation; yi, t0 is the magnitude of the same indicator at the beginning; $\mathrm{B}$ is a constant term of the regression function; $\mathrm{ui}, \mathrm{t} 0, \mathrm{t} 0+\mathrm{T}$ is the residual deviation from the linear trend; $\beta$ is the coefficient of the linear term of the regression function. Convergence occurs when the calculated coefficient $\beta$ is negative. Student's t-test is used to verify statistical significance, the strength of dependence can be measured by correlation coefficient. The countries under comparison differ significantly in the number of inhabitants, size of the economy, but also in the dynamics of changes in these indicators.

In this paper, the following abbreviations are used: EU = European Union, OIV = Organisation of Vine and Wine.

\section{Results and discussion}

In this chapter, the individual results are processed in a clear way, and are continuously graphically expressed, interpreted, commented on and discussed. Selected countries with consumption over 2 million hectoliters are examined through beta convergence. Then, the relationship between average temperatures and wine consumption in the given countries is observed.

First, the consumption of wine (including sparkling wine) per capita for each year was calculated. Only the first and last year, i.e. 1995 and 2020, were used for the calculation from the entire time series (see Table 1).

Wine consumption in selected countries in absolute terms and per capita and in 1995 and 2020, the change in relative consumption between these years

Table 1

\begin{tabular}{|c|c|c|c|c|c|}
\hline & \multicolumn{2}{|c|}{$\begin{array}{c}\text { Absolute consumption } \\
\text { (Millions hectolitre per Year) }\end{array}$} & \multicolumn{2}{c|}{$\begin{array}{c}\text { Relative consumption } \\
\text { per Capita (Litres per Year) }\end{array}$} & $\begin{array}{c}\text { Relative change } \\
\text { per Capita (\%) }\end{array}$ \\
\hline & 1995 & 2020 & 1995 & 2020 & $1995-2020$ \\
\hline France & 36,5 & 24,7 & 63,1 & 37,9 & $-40 \%$ \\
\hline Italy & 35,6 & 24,5 & 62,7 & 41,1 & $-34 \%$ \\
\hline Germany & 18,7 & 19,8 & 23,0 & 23,8 & $4 \%$ \\
\hline United Kindom & 6,3 & 13,3 & 10,9 & 19,8 & $83 \%$ \\
\hline Spain & 15,3 & 9,6 & 38,9 & 20,3 & $-48 \%$ \\
\hline Portugal & 5,7 & 4,6 & 56,6 & 44,7 & $-21 \%$ \\
\hline Romania & 6,6 & 3,8 & 28,9 & 19,7 & $-32 \%$ \\
\hline Netherlands & 2,2 & 3,5 & 14,0 & 20,1 & $44 \%$ \\
\hline Belgium & 2,5 & 2,6 & 24,9 & 22,6 & $-9 \%$ \\
\hline Switzerland & 2,8 & 2,6 & 39,8 & 30,0 & $-25 \%$ \\
\hline Austria & 2,5 & 2,3 & 32,0 & 25,7 & $-20 \%$ \\
\hline Sweden & 1,1 & 2,2 & 12,1 & 21,2 & $75 \%$ \\
\hline Czechia & 0,6 & 2,1 & 6,2 & 19,6 & $218 \%$ \\
\hline Russia & 6,9 & 10,3 & 4,7 & 7,0 & $51 \%$ \\
\hline
\end{tabular}

Source: own results, according to Eurostat (2021), 0IV (2021a; 2021c), Statista (2021).

Table 1 shows only the values of these two years, and Figure 1 clearly shows the course of consumption for the entire period 1995-2020 observed in the selected European countries.

The relative change expresses the difference between the two years as a percentage of consumption in 1995. Positive values mean growth, negative values express decline.

Figure 1 shows the development of wine consumption in selected countries over the last 25 years. There is a large dispersion of values between countries at the beginning of this period. The countries of south-eastern Europe, such as France, Italy or Portugal, had a wine consumption of around 60 liters per capita per year, while the countries of the north and east (United Kingdom, Sweden, the Netherlands) had 3 times lower consumption. The countries of the newly defunct Eastern Bloc, which are represented in this article by the Czech Republic and the Russian Federation, were characterized by even lower wine consumption. 


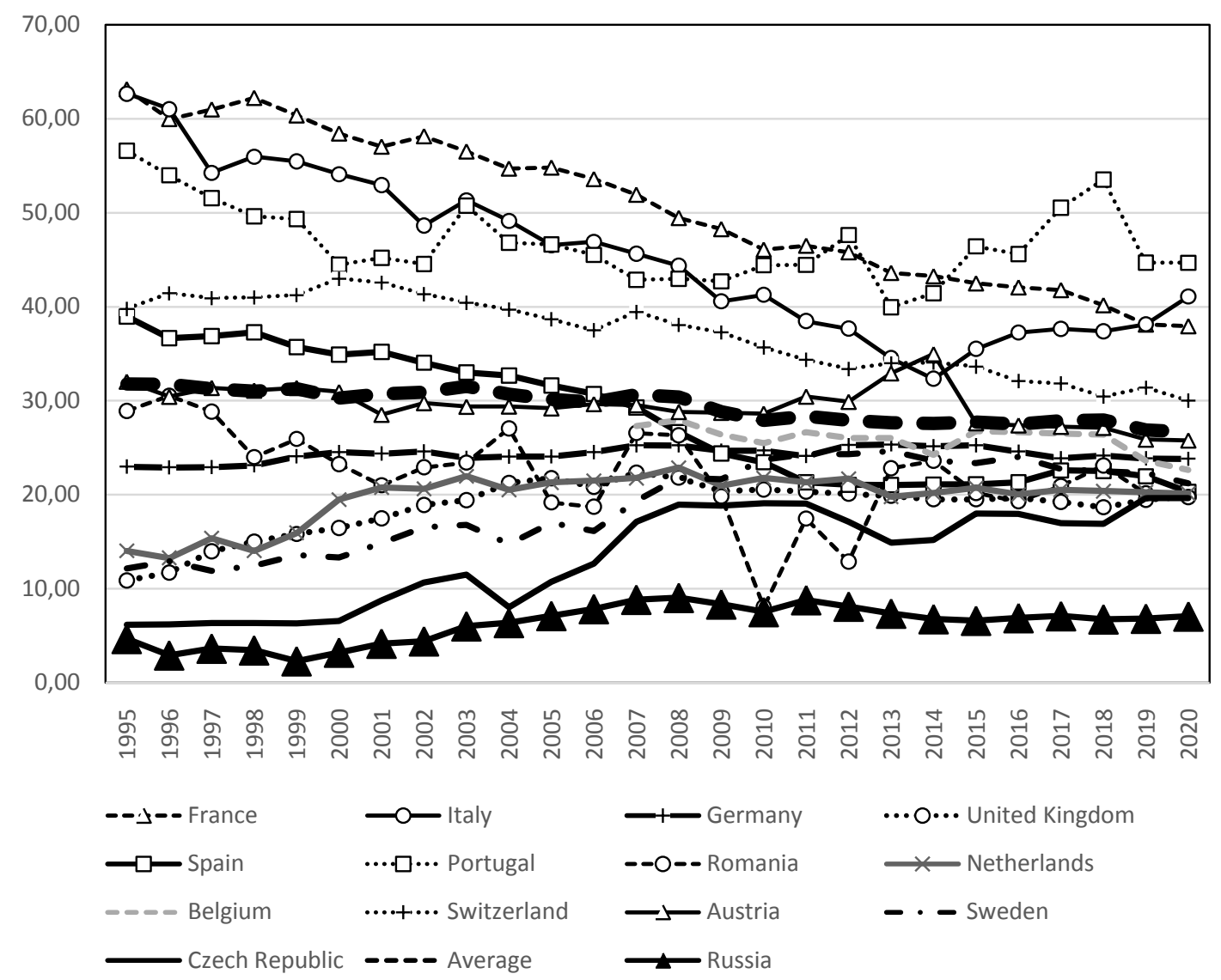

Fig. 1. Development of wine consumption per capita in selected European countries in the years 1995-2020 Source: own processing according to Eurostat, 2021; 0IV, 2019; 0IV, 2021; Statista, 2021.

Since the 1990s, there has been a large-scale cultural and trade exchange throughout Europe, previously divided by the Iron Curtain. Like other globalization trends, this exchange has manifested itself in the convergence of consumer preferences (in this case in wine consumption) like many simiar studies report (Chiabai et al., 2014). In countries with initially very high consumption, there is a decrease, in countries with initial low consumption, on the contrary, an increase in wine consumption occurs. During the period under review, average consumption also fell slightly, but the convergence trend was much more pronounced. The decline is most pronounced in the example of France, a traditional wine country, where consumption of wine declined by $40 \%$ from the 63 liters per capita per year to 38 liters per year (Ugaglia et al., 2019). Quite a different pattern can be found in the Czech Republic which has always been a traditional beer-drinking country. However, the wine consumption per capita for the Czechs has more than tripled from 6 liters per capita (Navrátilová et al., 2021).

Another specific story in wine-drinking is represented by Russia with its consumption of wine per capita increasing by half in the period under review and thus approached the European average, but even so it remains at only about a third of the European average. However, this peculiarity can be explained by the tradition and specific development of viticulture and wine-making in this state. Alcohol consumption in Russia is based on historical cultural patterns. Cicia et al. (2013) state that wine as an alcoholic beverage is in third place in Russian society in terms of consumer choice after vodka and beer. Based on their research, Keenan et al. (2014) also expressed the view that men in Russia choose stronger drinks than wine when consuming alcohol. In the 1970s, the former Soviet Union was the third largest producer in the world. At the end of the last century, however, the total share of the former Soviet republics fell to only $3 \%$ of the world production. The Gorbachev era campaign against alcohol in the 1980s had a negative effect on the state of viticulture (Johnson, Robinson, 2019). After the collapse of the Soviet Union in 1992, the demand for wine was very low. Many vineyards were grubbed up or abandoned during the 1980s and 1990s. Most production companies were forced to switch to processing grapes as a raw material from 
imports (Sedlo, 2020; Johnson, Robinson, 2019). Only a small part of Russia is suitable for growing vines in terms of climatic conditions (Kudryashova, Casetti, 2021). The main wine-growing areas are now located in the Krasnodar region, where more than half of the Russian vineyards are located (Sedlo, 2020). Other wine-growing areas are the Rostov region, the Stavropol region, Dagestan and Crimea (Johnson, Robinson, 2019). New vineyards have been planted in Russia over the last two decades, and new economic and legal measures have recently been taken to support domestic wine production and the overall modernization of the wine industry. In 2020, the Act on Viticulture and Enology came into force, which creates the basic preconditions for the development of the wine sector (Kudryashova, Casetti, 2021) and thus contributes to increasing the competitiveness of Russian wine on international markets (Sedlo, 2020).

The convergence of consumer preferences, which is evident from Fig. 1, is further verified statistically. The beta-convergence method was chosen for verification. It examines the relationship between the initial value and growth, as shown in the following figure (Fig. 2).

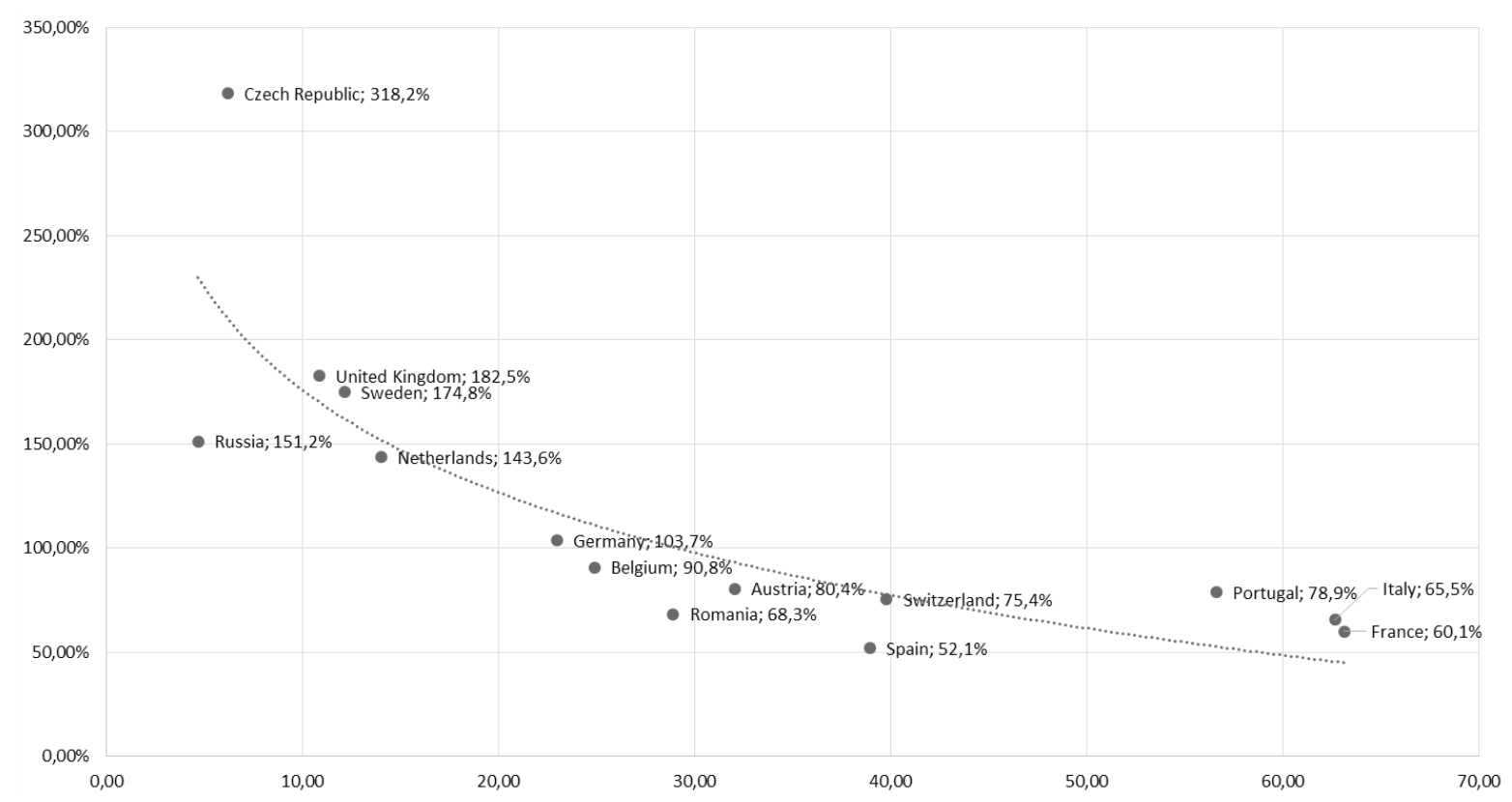

Fig. 2. Relative change in wine consumption per capita and year by 2020, depending on its consumption in 1995

Source: own processing according to Eurostat, 2021; 0IV, 2019; 0IV, 2021; Statista, 2021.

Graph 2 provides a different perspective on the data shown in Graph 1. It shows the relative change in wine consumption per capita between selected countries, not depending on time, but on the initial size of this consumption. There is a more pronounced trend that while in countries with low initial consumption there is an increase or only a small decrease, in countries with high initial consumption, the decrease is much more pronounced.

The convergence trend (dotted curve in the graph) can be statistically tested by the beta-convergence method. It was verified that the logarithmic model of the dependence of the absolute difference in consumption depending on the initial value of consumption (beta parameter of the linear dependence) is statistically significant $(\mathrm{p}<0.01)$ and describes the convergence trend very well. The value of the correlation coefficient $\mathrm{r}=-0.88$ shows a high degree of dependence, and thus the large explanatory power of the convergence model.

Although the convergence trend shows that globalization is blurring the differences between consumer preferences, it does not explain why these differences exist and persist. Therefore, the hypothesis that these differences are related to the climatic conditions of selected countries was further investigated. The average temperature in a given country according to World Bank statistics in the decade preceding the year under review was used to quantify climatic conditions. The data are summarized in the following table (Table 2).

Table 2 depicted aboe demonstrates that countries with warmer climate (e.g. Portugal, Spain, Italy, France) typically yield higher wine consumption per capita, while countries with colder climates have low or at most average consumption. Climatic conditions in Russia, which has the lowest average temperatures of the countries studied, also explain its lowest wine consumption. 
Table 2

Average temperature and wine consumption per capita in 1995 and 2020

\begin{tabular}{|c|c|c|c|c|}
\hline & \multicolumn{2}{|c|}{ Average temperature $\left({ }^{\circ} \mathbf{C}\right)$} & Consumption per Capita (Litres per Year) \\
\hline & $1985-1995$ & $2010-2020$ & 1995 & 2020 \\
\hline France & 11,11 & 11,18 & 63,1 & 37,9 \\
\hline Italy & 12,36 & 12,40 & 62,7 & 41,1 \\
\hline Germany & 9,03 & 9,09 & 23,0 & 23,8 \\
\hline United Kindom & 8,70 & 8,75 & 10,9 & 19,8 \\
\hline Spain & 13,59 & 13,63 & 38,9 & 20,3 \\
\hline Portugal & 15,37 & 15,40 & 56,6 & 44,7 \\
\hline Romania & 9,02 & 9,07 & 28,9 & 19,7 \\
\hline Netherlands & 9,76 & 9,82 & 14,0 & 20,1 \\
\hline Belgium & 10,02 & 10,09 & 24,9 & 22,6 \\
\hline Switzerland & 5,50 & 5,56 & 39,8 & 30,0 \\
\hline Austria & 6,6 & 6,60 & 32,0 & 25,7 \\
\hline Sweden & 2,45 & 2,52 & 12,1 & 21,2 \\
\hline Czechia & 8,08 & 8,13 & 6,2 & 19,6 \\
\hline Russia & $-4,59$ & $-4,55$ & 4,7 & 7,0 \\
\hline
\end{tabular}

Source: own processing according to Eurostat, 2021; 0IV, 2019; 0IV, 2021; Statista, 2021; WBG, 2021.

The results obtained also confirm the claims of Cox and Bridwell (2007), who state that although France and Italy are the largest consumers of wine in the world in terms of total volume, in terms of per capita conversion wine consumption is declining in these traditional markets. Lombardi et al. (2016) show that despite the existence of new markets and an intensifying competitive environment, Europe remains the largest market in terms of wine production and consumption. Cox and Bridwell (2007) highlight the growing trend in wine consumption per capita in the UK and also emphasize the overall importance of this growing wine market.

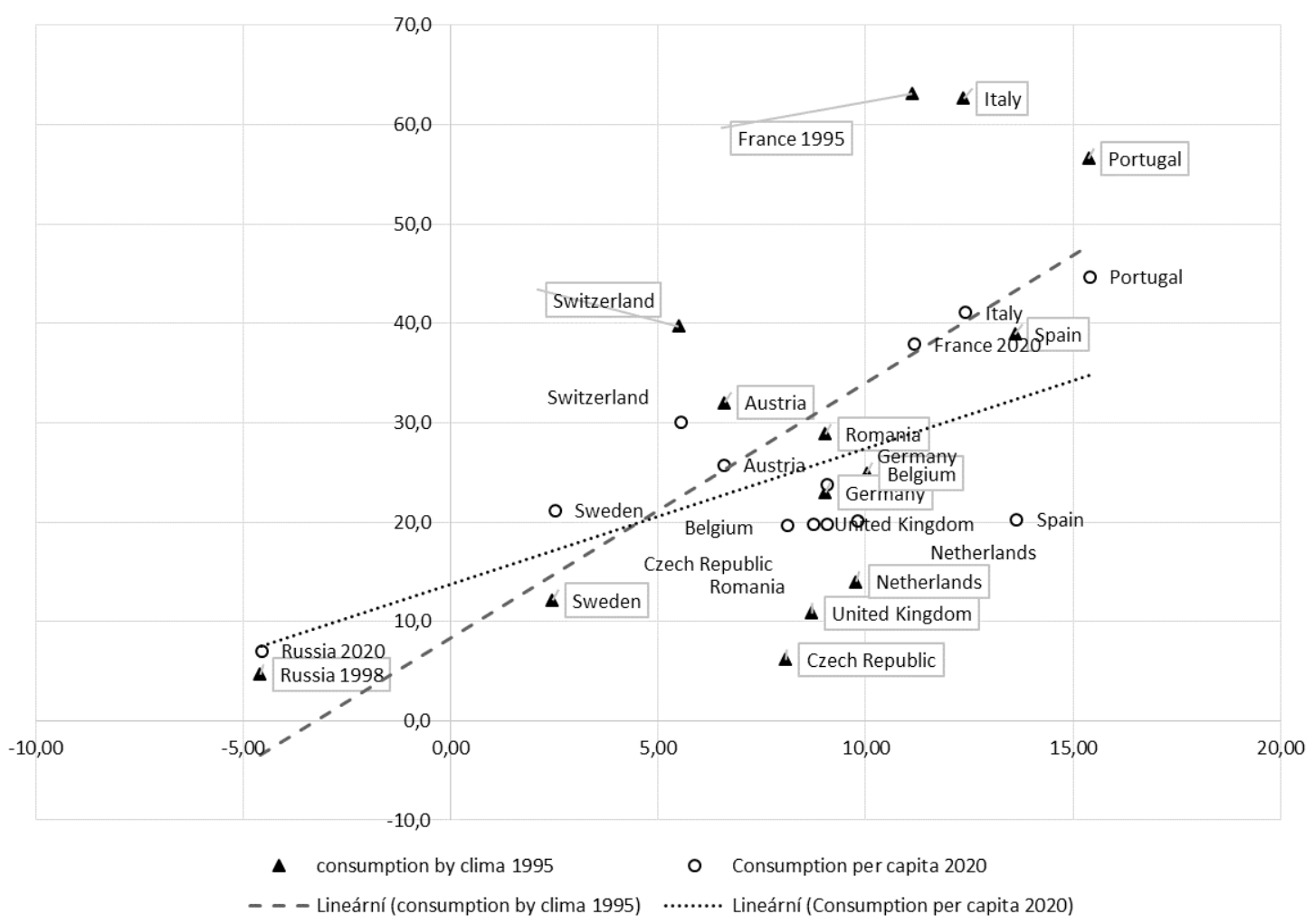

Fig. 3. Dependence of consumption on climatic conditions in selected countries in 1995 and 2020 Source: own processing according to Eurostat, 2021; 0IV, 2019; 0IV, 2021; Statista, 2021; WBG, 2021. 
The relationship between wine consumption and climate is described in Fig. 3. It shows the consumption of wine in selected countries depending on the average annual temperature in 1995 and 2020. In both years under review, this dependence is statistically significant ( $p$-value of t-tests is 0.015 and 0.008 ) and the correlation rate gradually increases (1995: $r=0.63 ; 2020: r=0.67)$. The graph shows the regression lines, modeling the relationship for both years described above. There is a noticeable change in inclination due to the previously described convergence in wine consumption. Convergence is a manifestation of globalization, which erases some of the differences between countries. However, globalization cannot completely erase the influence of natural conditions or historical peculiarities. National customs are also historically adapted to the climate, including the preferred types of beverages.

Schultz (2010) believes that population growth and the lack of suitable agricultural land for food production, together with climate change, will be the factors that require better resource management in grape-producing areas. Guy (2011) emphasizes the value of "terroir" as a marketing investment in shaping the brand identity of products as a guarantee and their authenticity. The most suitable solution in terms of building "terroir" seems to be the cultivation of varieties that will be adapted to local conditions so that the full ripeness of grapes is reached by the end of the growing season (van Leeuwen, Seguin, 2007).

Thus, viticulture and wine-making face a number of challenges in terms of climate change. The success of these steps will depend on many factors. Kirovski (2011) points out that the future shape of the wine market and its marketing will be strongly influenced by countries that have great consumer potential in wine consumption, such as Russia, but also China and India. Based on their research, Cholette and Castaldi (2005) identified factors that are crucial in terms of the competition in the international wine industry, such as (i) the existence of a strong existing domestic market, (ii) the potential of the domestic market, (iii) the advantage of economies of scale, (iv) the ability of the wine industry to adapt to change, (v) the potential of the sector to attract foreign investment. Tate (2010) talks about the problem of global warming and states that the varietal composition of the vine, which is currently suitable for specific wine-growing areas, and will change in the future. The author also points out that climate change will inevitably be accompanied by changes in temperature and precipitation, which will affect production conditions worldwide. Zhu et al. (2016) emphasize the importance of introducing adaptation measures in the context of climate change, such as the relocation of vineyards or the introduction of new vine varieties.

Sellers (2016) considers sustainability to be one of the most important challenges for viticulture in the last decade. Borsellino et al. (2016) also share this view and state that the implementation of this concept represents "environmental soundness, social equity and economic feasibility". Zucca et al. (2009) add that the achievement of sustainable agricultural practices is a process that is conditioned by a number of small, realistic and measurable goals. Doloreux and Frigon (2016), based on their research conducted among Canadian wine companies, state the need for innovative approaches in the wine industry with an emphasis on technology, a new concept of business practice and marketing activities. This is also confirmed by Nazzaro et al. (2016), who point out the importance of the application of Corporate Social Responsibility in the context of innovation activities in the wine sector, because environmental and social aspects are important in the eyes of consumers. Montaigne et al. (2016) view the problem in the same way, believing that in the long run, wine production is influenced by consumer preferences and thus social pressure to protect the environment (Scozzafava et al., 2018). Cholette and Castaldi (2005) draw attention to the complexity of patterns of consumer behavior in wine consumers, which must be taken into account.

Wine producers still compete strongly in terms of product differentiation (Menghini. 2018; Zucca et al., 2009), so wines produced under sustainable production methods can be considered a market opportunity for wine-makers within a competitive environment (Sellers, 2016). With regard to the above, Sellers (2016) analyzed the willingness of Spanish consumers to pay a higher price for wines from sustainable production. As part of his research, the author noted different results in individual market segments and stated the importance of the influence of socio-economic characteristics of consumers and the level of knowledge about wine culture on respondents' answers. At the same time, however, he draws attention to the fact that the intention to purchase a product may not always correspond to the consumer's actual shopping behavior.

In addition, Sellers (2016) analyzed the willingness of Spanish consumers to pay a higher price for wines from sustainable production. As part of his research, the author noted different results in individual market segments and stated the importance of the influence of socio-economic characteristics of consumers and the level of knowledge about wine culture on respondents' answers. At the same time, however, he draws attention to the fact that the intention to purchase a product may not always correspond to the consumer's actual shopping behavior. Platania et al. (2016) emphasize the importance of the suitability of the wine 
sales environment, because the customer wants to perceive the experience comprehensively when making a purchase. From this point of view, wine can be perceived as an experiential commodity (Dressler, 2016). The purchase of wine is also strongly influenced by new technologies and applications, the use of which depends on ease of use and on the perceived subjective value of the use of technology (del Mastio et al., 2016). Banks and Overton (2009) predict that "wine is, and will continue to be, a global industry but one, more than any other, which is attached to different places and manifested locally in many different ways".

\section{Conclusions}

All in all, we can see that viticulture and wine-making represent a traditional branch of the agri-food complex which has found itself in the midst of dynamic changes in recent decades. Territorial changes have taken place in the wine industry, mainly in the form of the successful expansion of new countries into world wine markets and a change in wine production in countries where wine-growing has a long history and tradition. In addition, institutional changes in the wide indistry have also collected their toll transforming the shape and the characteristics of the wine drinking as we useed to know it. All this has led to increased competition in the field of wine sales on the global world market. In today's modern society, however, there are also significant changes in terms of consumer behavior and preferences regarding wine, but also alcoholic beverages in general, which has led to changes in wine consumption worldwide. Global climate change has brought a number of real issues and new challenges to the wine sector, as changes in temperatures and precipitation worldwide require vine growers to change their varietal composition and raise concerns about the future of existing vineyards.

Overall, the aim of this article was to evaluate wine consumption in selected European countries and Russia in the context of climate employign the popular beta convergence method. Our results show that globalization processes are blurring some of the differences between countries, which are converging in the long when it comes to the wine consumption.

Therefore, the main theoretical contribution of the article is the elaboration of a selected issue and a literary review. The practical benefit of the article is the presentation of data, which was calculated using selected statistical functions. It can be considered as a limitation of the article that the research was carried out only in selected countries within Europe. Another direction of research is a possible focus on the comparison of the so-called New and Old-World states, or orientation to a more detailed examination of new consumer markets.

\section{Литература / References}

Abrhám J., Lžčă̌ P. (2018). Risk management in the sustainable development: Analysis of a selected key industry. Journal of Security and Sustainability Issues 8(2): 171-180. https://doi.org/10.9770/jssi.2018.8.2(5)

Apopei L., Papaghiuc V. (2021). Reflections on the dynamics of vineyard surfaces and wine activities in the interval 1995-2020 at global and regional level. Internation Journal of Economics, Business and Management Research 5(4): 175-185.

Aylward D. (2003). A documentary of innovation support among New World wine industries. Journal of Wine Research 14(1): 31-43. https://doi.org/10.1080/0957126032000114991

Banks G., Overton J. (2010). Old World, New World, Third World? Reconceptualising the worlds of wine. Journal of Wine Research 21(1): 57-75. https://doi.org/10.1080/09571264.2010.495854

Barro Sala i Martin Barro R., Sala-i-Martin X. (2003). Economic growth. Cambridge: MIT Press.

Beňuš 0., Bielik P., Turčeková N., Adamičková I. (2021). Sustainability of the Slovak spirits industry in the single market of the EU. Sustainability 13(10): 1-17. https://doi.org/10.3390/su13105692

Berbegal C., Fragasso M., Russo P., Bimbo F., Grieco F., Spano G., Capozzi V. (2019). Climate changes and food quality: The potential of microbial activities as mitigating strategies in the wine sector. Fermentation 5(4): art.nr. 85. https://doi.org/10.3390/fermentation5040085

Borsellino V., Migliore G., D'Acquisto M., Franco C., Asciuto A., Schimmenti E. (2016). 'Green' wine through a responsible and efficient production: A case study of a sustainable Sicilian wine producer. Agriculture and Agricultural Science Procedia 8: 186-192. https://doi.org/10.1016/j.aaspro.2016.02.092

Chiabai A., Platt S., Strielkowski W. (2014). Eliciting users' preferences for cultural heritage and tourism-related e-services: A tale of three European cities. Tourism Economics 20(2): 263-277. https://doi.org/10.5367/ te. 2013.0290 
Cholette S., Castaldi R. (2005). The globalization in the wine industry: Impications old and new world producers (https://www.researchgate.net/publication/265748503_The_globalization_of_the_ wine_industry_Implications_for_old_and_new_world_producers - accessed November 18 2021).

Cholette S., Castaldi R. (2005). The globalization in the wine industry: Impications old and new world producers (https://www.researchgate.net/publication/265748503_The_globalization_of_the_ wine_industry_Implications_for_old_and_new_world_producers - accessed November 18 2021).

Cicia G., Cembalo L., Del Giudice T., Scarpa R. (2013). Country-of-Origin Effects on Russian Wine Consumers. Joumal of Food Products Marketing 19(4): 247-260. https://doi.org/10.1080/10454446.2013.724369

Cox J., Bridwell L. (2007). Australian companies using globalization to disrupt the ancient wine industry. Competetivness Review: An International Business Journa 17(4): 209-221. https://doi. org/10.1108/10595420710844307

Cradock-Henry N., Fountain J. (2019). Characterising resilience in the wine industry: Insights and evidence from Marlborough, New Zealand. Environmental Science \& Policy 94: 182-190. https:// doi.org/10.1016/j.envsci.2019.01.015

Davidson S., De Filippi P., Potts J. (2018). Blockchains and the economic institutions of capitalism. Journal of Institutional Economics 14(4):639-658. https://doi.org/10.1017/S1744137417000200

Del Mastio A., Caldelli R., Casini M., Manetti M. (2016). SMARTVIN0 project: When wine can benefit from ICT. Wine Economics and Policy 5(2): 142-149. https://doi.org/10.1016/j.wep.2016.11.003

Doloreux D., Frigon A. (2019). Understanding innovation in Canadian wine regions: An exploratory study. British Food Journal 121(4): 882-896. https://doi.org/10.1108/BFJ-10-2018-0691

Dressler M. (2016). Prosumers in the wine market: An explorative study. Wine Economics and Policy 5(1): 24-32. https://doi.org/10.1016/j.wep.2016.04.002

Duchêne E., Huard F., Dumas V.,Schneider C. and Merdinoglu D. (2010). The challenge of adapting grapevine varieties to climate change. Climate Research 41: 193-204. https://doi.org/10.3354/cr00850

Eurostat (2021). Population without the citizenship of the reporting country. Bruxelles: European Statitical System (https://ec.europa.eu/eurostat/databrowser/view/tps00157/default/table?lang=en _ accessed September 18 2021).

Ferrer Lorenzo J., Maza Rubio M., Abella Garcés S. (2018). The competitive advantage in business, capabilities and strategy. What general performance factors are found in the Spanish wine industry? Wine Economics and Policy 7(2): 94-108. https://doi.org/10.1016/j.wep.2018.04.001

Green S. (2018). The European Union and action on climate change, through the lens of the wine industry. Wine Economics and Policy 7(2): 120-127. https://doi.org/10.1016/j.wep.2018.06.002

Guy K. (2011). Silence and savoir-faire in the marketing of products of the terroir. Modern \& Contemporary France. 19(4): 459-475. https://doi.org/10.1080/09639489.2011.610165

Hannah L., Roehrdanz P., Ikegami M., Shepard A., Shaw M., Tabor G., Zhi L., Marquet P., Hijmans R. (2013). Climate change, wine, and conservation. Proc. Natl. Acad. Sci. 110: 6907-6912. https://doi.org/10.1073/ pnas. 1210127110

Hendl J. (2005) Kvalitativní Výzkum: Základní Metody a Aplikace. Praha: Portál.

Hendl J., Remr J. (2017) Metody Výzkumu a Evaluace. Praha: Portál.

Hinings B., Gegenhuber T., Greenwood R. (2018). Digital innovation and transformation: An institutional perspective. Information and Organization 28(1): 52-61. https://doi.org/10.1016/j.infoandorg.2018.02.004

Jamali H., Steel C., Mohammadi E. (2020). Wine research and its relationship with wine production: A scientometric analysis of global trends. Australian Journal of Grape and Wine Research 26(2): 130-138. https://doi.org/10.1111/ajgw.12422

Janšto E., Hennyeyová K., Šugrová M., Petrilák M. (2018). Comparison of wine production and consumption: Case study of Slovakia and Czech Republic, pp. 789-800. In: International Scientific Days 2018. Towards Productive, Sustainable and Resilient Global Agriculture and Food Systems: Proceedings.

Johnson H., Robinson J. (2019). The World Atlas of Wine. Ottawa: Octopus Books.

Katunar J., Zaninović V., Katunar H. (2021). Macroeconomic determinants of wine production in the European Union. Ekonomska Misao i Praksa 30(1): 43-55. https://doi.org/10.17818/EMIP/2021/1.2 
Keenan K., Kenward M., Grundy E., Leon D. (2014). The impact of alcohol consumption on patterns of union formation in Russia 1998-2010: An assessment using longitudinal data. Population Studies 68(3): 283-303. https://doi.org/10.1080/00324728.2014.955045

Khoshnava S., Rostami R., Zin R., Štreimikienė D., Yousefpour A., Strielkowski W., Mardani A. (2019). Aligning the criteria of green economy (GE) and sustainable development goals (SDGs) to implement sustainable development. Sustainability 11(17): 4615. https://doi.org/10.3390/su11174615

Kirovski P. (2012). Global trends in the wine sector. Agricultural Economics and Management 56(5): 3-13.

Koch B., Oehl F. (2018). Climate change favors grapevine production in temperate zones. Agricultural Sciences 9(3): 247-263. https://doi.org/10.4236/as.2018.93019

Koudelková P., Strielkowski W., Hejlová D. (2015). Corruption and system change in the Czech Republic: Firm-level evidence. Danube: Law, Economics and Social Issues Review 6(1): 25-46. https://doi.org/10.1515/danb-2015-0002

KudryashovaE.,CasettiM. (2021).Digital technologiesin wine sector: Russianlegislator preferences.IOPConference Series: Earth and Environmental Science 699(1). https://doi.org/10.1088/1755-1315/699/1/012002

Lombardi P., Dal Bianco A., Freda R., Caracciolo F., Cembalo L. (2016). Development and trade competitiveness of the European wine sector: A gravity analysis of intra-EU flows. Wine Economics and Policy 5(1): 50-59. https://doi.org/10.1016/j.wep.2015.12.002

Maicas S., Mateo J. (2020). Sustainability of wine production. Sustainability 12(2): 1-10. https:// doi.org/10.3390/su12020559

Marunelu I. (2020). Research on the small peasant individual households in Romania within the framework of sustainable agriculture. Scientific Papers-Series Management Economic Engineering in Agriculture and Rural Development 20(1): 341-146.

Menghini S. (2018). Designations of origin and organic wines in Italy: Standardisation and differentiation in market dynamics. Wine Economics and Policy 7(2): 85-87. https://doi.org/10.1016/j.wep.2018.11.003

Mira de Orduña R. (2010). Climate change associated effects on grape and wine quality and production. Food Research International 43(7): 1844-1855. https://doi.org/10.1016/j.foodres.2010.05.001

Mohajan H. (2018). Qualitative research methodology in social sciences and related subjects. Journal of Economic Development, Environment and People 7(1): 23-48. https://doi.org/10.26458/jedep.v7i1.571

Montaigne E., Coelho A., Khefifi L. (2016). Economic issues and perspectives on innovation in new resistant grapevine varieties in France. Wine Economics and Policy 5(2): 73-77. https://doi.org/10.1016/j.wep.2016.11.002

Mosedale J., Abernethy K., Smart R., Wilson R., Maclean I. (2016). Climate change impacts and adaptive strategies: Lessons from the grapevine. Global Change Biology 22(11): 3814-3828. https://doi.org/10.1111/gcb.13406

Navrátilová M., Beranová M., Severová L., Šrédl K., Svoboda R., Abrhám J. (2021). The impact of climate change on the sugar content of grapes and the sustainability of their production in the Czech Republic. Sustainability 13(1): 222. https://doi.org/10.3390/su13010222

Nazzaro C., Marotta G., Rivetti F. (2016). Responsible innovation in the wine sector: A distinctive value strategy. Agriculture and Agricultural Science Procedia 8: 509-515. https://doi.org/10.1016/j.aaspro.2016.02.058

OIV (2019). Annual assessment - 2019 statistical report on world vitiviniculture. Paris: Internatonal Organisation of Vine and Wine (https://www.oiv.int/en/technical-standards-and-documents/ statistical-analysis/annual-assessment - accessed 0ctober 20 2021).

OIV (2020). State of the world vitivinicultural sector in 2020. Paris: Internatonal Organisation of Vine and Wine (https://www.oiv.int/public/medias/7909/oiv-state-of-the-world-vitiviniculturalsector-in-2020.pdf - accessed 0ctober 5 2021).

OIV (2021). Statistical data - The state of vitiviniculture in the world and the statistical information. Paris: Internatonal Organisation of Vine and Wine (https://www.oiv.int/en/technical-standardsand-documents/statistical-analysis/statistical-data - accessed October 27 2021).

Platania M., Platania S., Santisi G. (2016). Entertainment marketing, experiential consumption and consumer behavior: The determinant of choice of wine in the store. Wine Economics and Policy 5(2): 87-95. https://doi.org/10.1016/j.wep.2016.10.001 
Pomarici E., Sardone R. (2020). EU wine policy in the framework of the CAP: Post-2020 challenges. Agricultural and Food Economics 8(1). https://doi.org/10.1186/s40100-020-00159-z

Pretty J., Benton T., Bharucha Z., Dicks L., Flora C., Godfray H., Goulson D., Hartley S., Lampkin N., Morris C., Pierzynski G., Prasad P., Reganold J., Rockström J., Smith P., Thome P., Wratten S. (2018). Global assessment of agricultural system redesign for sustainable intensification. Nature Sustainability 1(8): 441-446.

Radović N., Milićević S. (2020). The examination and assessment of winery business and contribution to the development of wine tourism of Serbia. Ekonomika Poljoprivrede 67(4): 1103-1123. https://doi.org/10.5937/ekoPolj2004103R

Richter B., Hanf J. (2021). Competitive strategies for wine cooperatives in the german wine industry. Wine Economics and Policy 9(2): 83-98. https://doi.org/10.36253/web-8872

Santos J., Fraga H., Malheiro A., Moutinho-Pereira J., Dinis L-T., Correia C., Moriondo M., Leolini L., Dibari C., Costafreda-Aumedes S., Kartschall T., Menz C., Molitor D., Junk J., Beyer M., Schultz H. (2020). A review of the potential climate change impacts and adaptation options for European viticulture. Applied Sciences 10(9). https://doi.org/10.3390/app10093092

Schultz H. (2010). Climate change and viticulture: Research needs for facing the future. Journal of Wine Research 21(2-3): 113-116. https://doi.org/10.1080/09571264.2010.530093

Scozzafava G., Gerini F., Dominici A., Contini C., Casini L. (2018). Reach for the stars: The impact on consumer preferences of introducing a new top-tier typology into a PD0 wine. Wine Economics and Policy 7(2): 140-152. https://doi.org/10.1016/j.wep.2018.09.001

Sedlo J. (2020). Vinařství ve světě: Data a fakta. Valtice: Národní vinařské centrum.

Sellers R. (2016). Would you pay a price premium for a sustainable wine? The voice of the Spanish consumer. Agriculture and Agricultural Science Procedia 8: 10-16. https://doi.org/10.1016/j.aaspro.2016.02.003

Statista (2021). Wine consumption worldwide in 2020, by country (in million hectolitres). New York: Statista (https://www.statista.com/statistics/858743/global-wine-consumption-by-country - accessed October 15 2021).

Tate A. (2010). Global warming's impact on wine. Journal of Wine Research 12(2): 95-109. https:// doi.org/10.1080/09571260120095012

Thorpe M. (2009). The globalisation of the wine industry: New world, old world and China. China Agricultural Economic Review 1(3): 301-313. https://doi.org/10.1108/17561370910958873

Tyslová I., Abrhám J., Horváthová Z., Rubáček F. (2020). Economic benefits of tourism: Cultural identity and tourism destinations in the Czech Republic. Terra Economicus 18(2): 139-154. https://doi.org/10.18522/2073-6606-2020-18-2-139-154

Ugaglia A., Cardebat J., Jiao L. (2019). The French wine industry, pp. 17-46. In: A. Ugaglia, J. Cardebat, A. Corsi (eds.) The Palgrave Handbook of Wine Industry Economics. Palgrave Macmillan, Cham. https://doi.org/10.1007/978-3-319-98633-3_2

Van Leeuwen C., Darriet P. (2016). The impact of climate change on viticulture and wine quality. Journal of Wine Economics 11(1): 150-167. https://doi.org/10.1017/jwe.2015.21

Van Leeuwen C., Seguin G. (2006). The concept of terroir in viticulture. Journal of Wine Research 17(1): 1-10. https://doi.org/10.1080/09571260600633135

WBG (2021). Climate change knowledge portal: For development practitioners and policy makers. Washington: World Bank Group (https://climateknowledgeportal.worldbank.org/contact-us accessed November 102021 ).

Werdelmann T. (2014). Quality and Value Creation on the Premium Wine Market. Journal of Applied Leadership and Management 3: 47-72.

Young A., Higgins M., Levy D. (2008). Sigma Convergence versus Beta Convergence: Evidence from U.S. County-Level Data. Journal of Money, Credit and Banking 40(5): 1083-1093. https://doi. org/10.1111/j.1538-4616.2008.00148.x

Zhu X., Moriondo M., van Ierland E., Trombi G., Bindi M. (2016). A model-based assessment of adaptation options for Chianti wine production in Tuscany (Italy) under climate change. Regional Environmental Change 16(1): 85-96. https://doi.org/10.1007/s10113-014-0622-z

Zucca G., Smith D., Mitry D. (2009). Sustainable viticulture and winery practices in California: What is it, and do customers care? International Journal of Wine Research 1: 189-194. https://doi.org/10.2147/IJWR.S5788 